\title{
STATISTICAL ANALYSIS OF MALIGNANT MELANOMA OF NASAL CAVITY AND PARANASAL SINUSES IN JAPAN
}

HISAKI SAITO, M. D., JIRO HOZAWA, M. D. and MINAKO YAMAGAMI, M. D.

Department of Otorhinolaryngology, Hirosaki University, School of Medicine, Hirosaki

Statistical analysis of malignant melanoma of nasal cavity and paranasal sinuses was performed on 143 cases which are composed of 11 cases treated at Hirosaki University from 1965 to 1981 and 132 cases collected from Japanese literature during the same period.

Age ranged from 1 to 85 years old and peak incidence was observed in the sixth and seventh decade. Average age was 58.8 years old and the male to female ratio was 1.24 to 1. A yearly incidence in average was 8.4 cases and showed an increase in the recent years. Primary lesion was observed more frequently in nasal cavity than paranasal sinuses, and the ratio was 6.4 to 1. Left to right ratio was 1.7 to 1. Lymph nodes or distant metastasis was observed in $62.5 \%$. Only 5 patients survived more than 5 years and 46 patients died within 5 years.

$$
\text { A } 86-0139-30389
$$

\section{本邦における鼻副鼻腔恶性黑色腫報告例の検討（1965-1981）}

$$
\begin{aligned}
& \text { 弘前大学医学部耳鼠咽喉科学教室（主任：朴沢二郎教授） }
\end{aligned}
$$

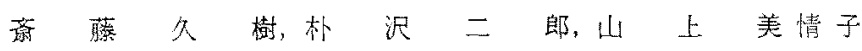

\section{Iはしめに}

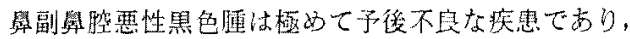

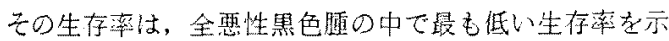

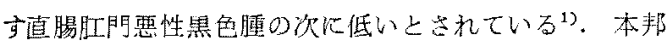

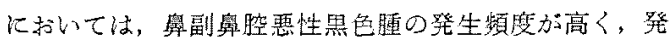

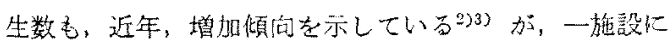

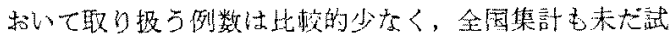

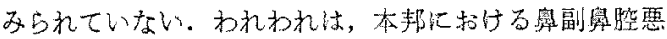
性黑色腫の動向を知るために，1965年1月から1981年12 月まての17年間に発表された本邦文献より集計した鼠副

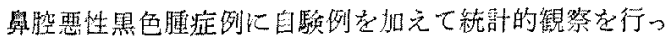
てみたので，若干の考察表加えて報留する。

\section{II 対象および方法}

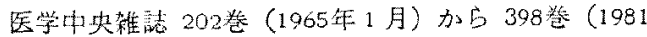

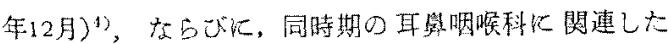

各医学芸老個々に赖索し，原著，学会抄録(迫加症列を

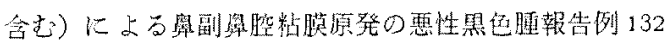
例を禁計し，同封期に力れわれが経験した11例（新鮮 例 8例, 再発転移例 2 例, 閔連病院新鮮例 1 例) 老加光 た143例を檢討対象とした。

\section{III結 果}

1. 年度别列数

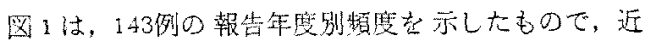
年增加傾问方認め方れた。年平均の発生数は８．4例であ 元。

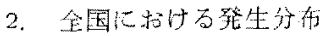

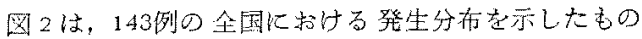
で，全国にわたってその報告が胃られ施が，米報些の地

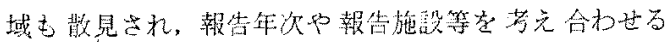
上，䒠際の軓生数はさらに多数にのほるこ上が推定され 


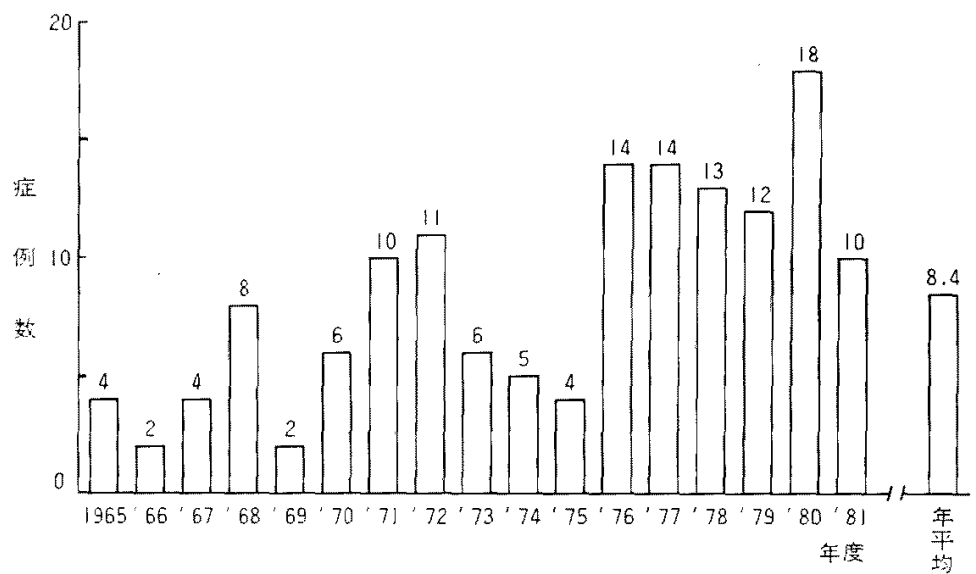

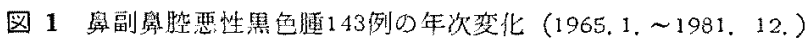

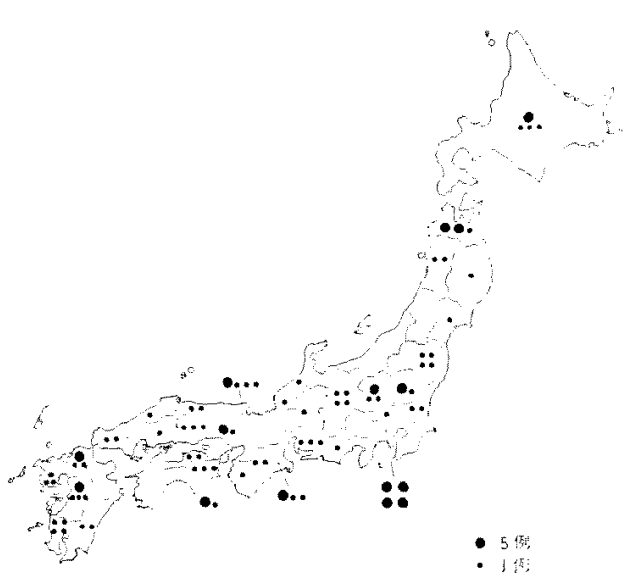

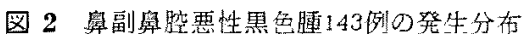
$(1965.1 . \sim 1981.12$.

t.

3. 年此就よ゙性別分有

四了は，143例の年齢扣よび性别分布を示したもので， 年龄は50藏代加660紫代に最も多?見られ，最小年龄は

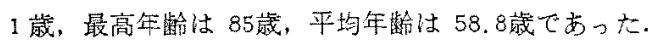
男女比咕，1.24:1 と男性に中p多加った。

4. 副発部位之左右别頻度

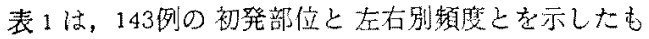
ので，奥腔原発は109例 $76.2 \%$ ，副䙹腔原発は17例

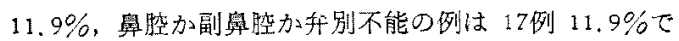

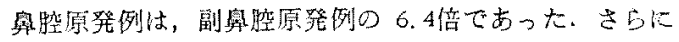

年撂：1歳一85藏

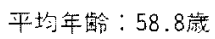

男: 女 $=1.24: 1$

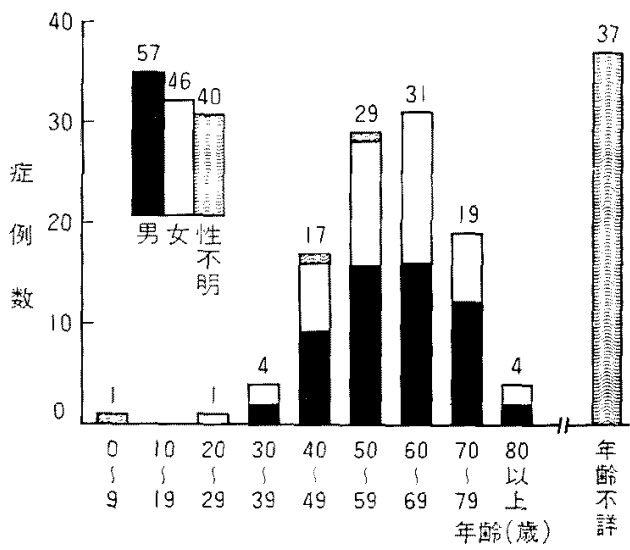

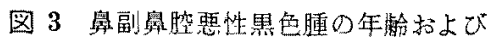
性别分布图 (1965，1， 1981,12.)

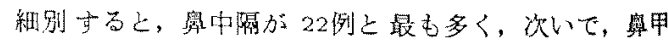
介21例(上丑介1例，中甲介4例，下甲介16例），臭

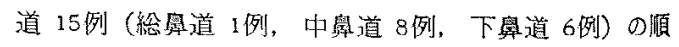
でった。左在別類廃は，左が在の1.7倍を占めてい t.

\section{5. 畭移}

143例中，リンバ節転移，ま大は，遠隔転移の有然の 萴戎のあったのは96例で，そのうち60例に転移を認

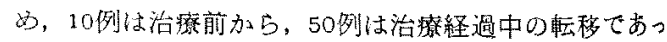




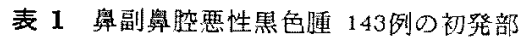
位已左右别頛度

\begin{tabular}{|c|c|c|}
\hline 初発部位 & 例数 & $\%$ \\
\hline 看腔 & 109 & 76.2 \\
\hline 舅中倩 & 22 & 15.4 \\
\hline 畄甲介 & 21 & 14.7 \\
\hline 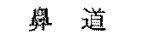 & 15 & 10.5 \\
\hline その他 & 3 & 2.1 \\
\hline 不 明 & 48 & 33.6 \\
\hline 副睤腔 & 17 & 11.9 \\
\hline 上靧洞 & 8 & 5.6 \\
\hline 箱骨洞 & 5 & 3.5 \\
\hline その他 & 1 & 0.7 \\
\hline 不 明 & 3 & 2.1 \\
\hline 舆副鼠整 & 17 & 11.9 \\
\hline
\end{tabular}

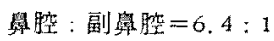

卖: 右 $=1.7: 1$

た、転移の北率は $62.5 \%$ ，過半数が全身䎐移であっ た.

6. 治療方法

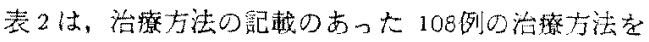
頻度別に挙げたもので, 手術学独が最も多く $19.4 \%$ ， 緢いて，手術，放射線，化学療法の併用が $13.9 \%$ ，手

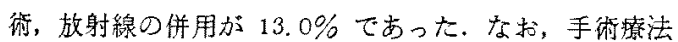

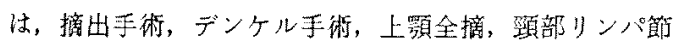

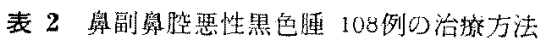

\begin{tabular}{|c|c|}
\hline 手街 & 21 例 $(19.4 \%)$ \\
\hline 手街+放的楾十化学療法 & $15 "(13.9 \%)$ \\
\hline 手街十放射線 & $14 "(13.0 \%)$ \\
\hline 手術斗化器療法 & $6 "(5.6 \%)$ \\
\hline 放射線 & $5 \|(4.6 \%)$ \\
\hline 放射線十兒疫療法 & $5 "(\|)$ \\
\hline 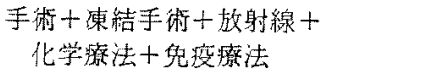 & $5 "(\|)$ \\
\hline 化学祭法 & $4 \pi(3.7 \%)$ \\
\hline 放射線+化学療法 & $4 \|(\|)$ \\
\hline 手術十兔疫療法 & $4 "(\|)$ \\
\hline 手街十化学察法十兔疫療法 & $4 \prime(" \prime)$ \\
\hline 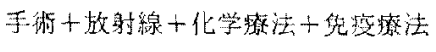 & $4 \|(\|)$ \\
\hline その他 & $17 "(15.7 \%)$ \\
\hline
\end{tabular}

综清等で 83洌 $77 \%$ ，淉結手術は 13例 $12 \%$ に，放 射線療法山， ${ }^{60} \mathrm{Co}$ ，ライナック X線， ${ }^{226} \mathrm{Ra}$ 針，中性子線 等を用いて 63例 58\% K, 化学噔法却 DTIC (dimethyl triazeno imidazole carboxamide), hydroxyurea, $\mathrm{ACNU}$ (nimustine $\mathrm{HCl}$ ), vincristine, bleomycin, methotrexate, endoxan, mitomycin C, 5-FU, adriamycin 等在用W $\tau$ 52例 48\% , 兒疫康法法, BCG (Bacillus CalmettGuérin), OK-432, PS-K (polysaccharide Kureha), Nocardia Cell Wall Skeleton, 丸山ワクチン (SSM) 等を用いて 35例 32\%に行われていた。 な批, 踣的新 しい治療法であるBCGに上る免疫療法, 渄結手術等は

表 3 鼻副鼻空覀性黑色腫84例の治療成績

年路：1藏～85藏（平均 59.5藏）性別：男 41 女 37 不明 6

\begin{tabular}{|c|c|c|c|c|c|c|c|c|c|c|c|c|c|c|c|c|}
\hline \multirow{2}{*}{ 铅穿期間 } & \multicolumn{2}{|c|}{ la } & \multicolumn{2}{|c|}{$\mathrm{Ib}$} & \multicolumn{2}{|c|}{1} & \multicolumn{2}{|c|}{ II } & \multicolumn{2}{|c|}{111} & \multicolumn{2}{|c|}{ I } & \multicolumn{2}{|c|}{ 不 明 } & \multicolumn{2}{|c|}{$\bar{z}$} \\
\hline & 生 & 死 & 生 & 死 & 生 & 死 & 生 & 死 & 生 & 死 & 生 & 死 & 生 & 死 & 生 & 死 \\
\hline $0-5$ & 6 & 4 & 2 & 3 & & 3 & 1 & & & & & 1 & 2 & 2 & 11 & 13 \\
\hline $6-11$ & 5 & 2 & 1 & 4 & 1 & 1 & 1 & 1 & & & & & 1 & 1 & 9 & 9 \\
\hline $12-17$ & 4 & 3 & 1 & 3 & 1 & 1 & & & & & & 1 & & & 6 & 8 \\
\hline $18-23$ & 1 & 1 & 1 & 1 & 1 & 2 & & 1 & & & & & & & 3 & 5 \\
\hline $24-29$ & 1 & 2 & & 1 & 1 & 1 & & 1 & & & & & & 1 & 2 & 6 \\
\hline $30-35$ & & & & & & & & & & & & & & & 0 & 0 \\
\hline $36-41$ & 1 & 1 & & & & 2 & & & & & & & & & 1 & 3 \\
\hline $42-47$ & 1 & & & & & & & & & & & & & 1 & 1 & 1 \\
\hline $48-53$ & & 1 & & & & & & & & & & & & & 0 & 1 \\
\hline $54-59$ & & & & & & & & & & & & & & & 0 & 0 \\
\hline $60 \rightarrow B L 上$ & 1 & 3 & 1 & & & & & & & & & & & & 2 & 3 \\
\hline 計 & 20 & 17 & 6 & 12 & 4 & 10 & 2 & 3 & 0 & 0 & 0 & 2 & 3 & 5 & 35 & 49 \\
\hline
\end{tabular}


1976年加b，DTIC によ䓃化学療法は1977年から, 中

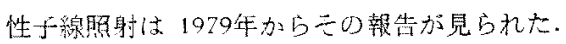

\section{7. 治療成績}

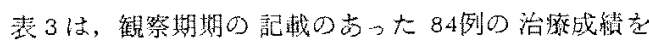

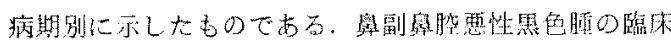
病期は末だ定的られていないのて，UICC第3版の皮成 覀性黒色腪の分類に染じて，次の上うに分数した。す わb，Iaは，原発腫猖が一側舆副畄腔粘膜に限局して

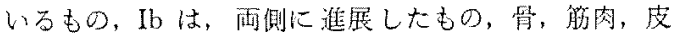

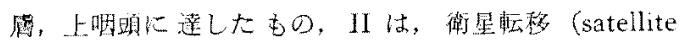
metastasis）のある屯の，所属りンパ節に枟移を認める 屯の, III は, 所属りンパ節以外のリンバ節に転移を認

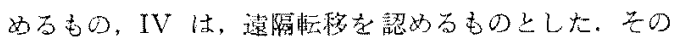

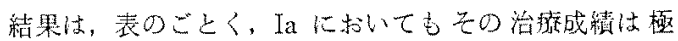
めて與く，37例中 2年以上生存と記载のあったのは11 例, 5 以上生存は 4 例, 2 年以内死亡は 10 例, 5 年以内死 亡は 14例で, stage Ib, II, IV においては，25例中， 2 年以上生存々記载のおった例は3挒，2年以内死亡は15 例ですった，表をもとにして，累積生存率を算定してみ ると, stage Ia の2 年生存落は $50.3 \%, 5$ 年生存率は $34.9 \%$, 全症例の 2 年生疗率は $30.8 \%, 5$ 年生存率は

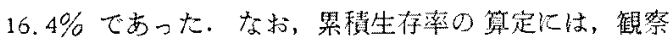

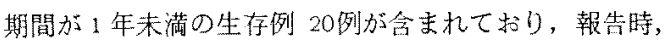
㽢に，再発転移を来していた症例香あり，実際の生存率 はさらに低いもの上推定された。

\section{IV 考 按}

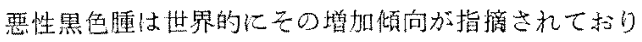

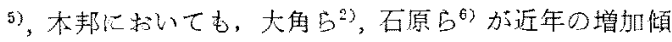
向を指摘している．米国の1979年の統計》では，年の発 生频度は，白人方，人口 10 万対 4.5 人，黑人か，人口

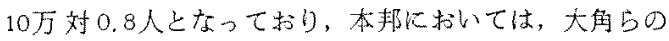
1970年3月加占1976年7月までの文献を梌索した統䚵 では，人口10万対 0.383 人，石原の1977年のアンケー 卜調查では，人口10万対0.3人となっている。倠性黑 色睡标，白人に比し日本人には少ないしされているが，

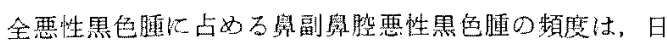
本人の方が $8 \%$ 台 $^{22}$ と, 白人の $1 \%$ 前後 ${ }^{1728}$ にくらへ

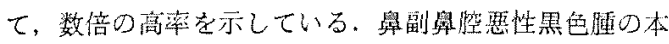

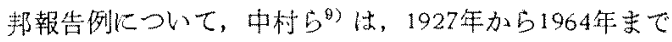
の38年間に64例集部しており，年平均発生数は 1.7 例 となっているが，今回のわれわれの集計では，年平均 8.4例と, 中村らの果計の5 倍弱在示し, 紧計万法の迕

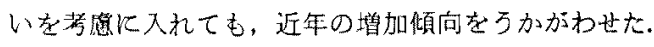

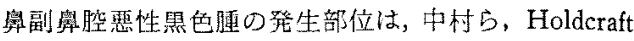

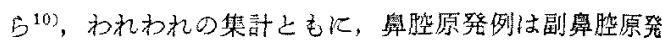

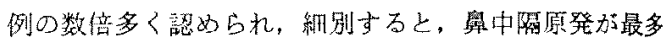

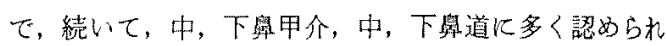

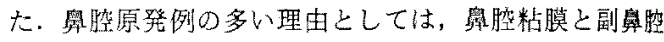
粘膜とのメラノサイトの分布の䧺い，鼻腔粘膜の方が剧

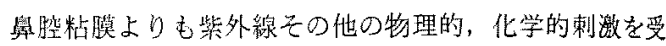
け男いことなどが考元られたが，これらと，恶性黑色随 発生との確実な因果関係は不明でる。.

舅副鬼空悪性照色腫の左右别頻度については，中村 は，右側に多いと報告し，今回のわれわれの集棓では左 側に多く，一定の傾向はなかった。

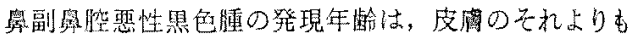

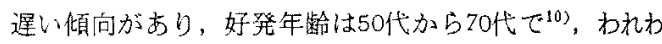
れの集計でる同様であった。 また，近年，70比，80代の

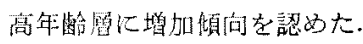

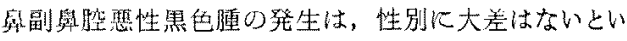
万報告が多いが，男性に多いという報告中，女性に多い という報告もあり，われわれの集計では，男性沉わずか に多いのみであった。

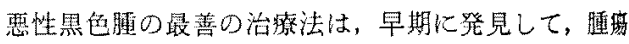
周辺を広沉に切除し，所属りンハ節を郭清することであ るが，奥副塄腔覀性黒色腫においては，その解剖学的满 造から早期発見は讙しく，切除範囲炕屯限界がある. 放射線撩法については，石原はは，速中性子線加もっと も效果が高いとしているが，それても，腫瘳の消失は2 例中 1 例のみですり，放射楾療法笛独で腫瘍を消失せし わることは国難で，外移療法との併用が望ましいとして いる。化学療法として, 現在, 主に使用されるものは DTIC であり ${ }^{12)}$, Bellet $5^{13)}$ は, DTIC 単独療法汇よ って，1，188例中 278 例(23.4\%) に効果起認めたと報告 している。最近, 石原 ${ }^{11)}$ は, DTIC, ACNU, vincristine に，bleomycinまたは，pepleomycinを組み合わせた DAVP療法を行い，今淩期待のできる治撩法で古ると 報笞している，免瘄法は，Morton $6^{14)}$ ○ BCG 投 与の報告以来，悪性黑色腄の治療飞際して，特に注目さ れている治㙩法で, 各種の, 主として非特異的兔度潦法

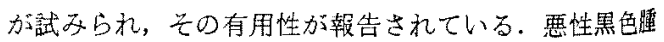
に和いては，㭧者自身の免度学的抵抗性への配層は，扁 平上皮癌の症例にむけるよりもはるかに重要視されてい

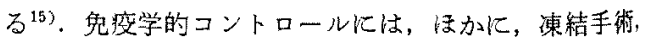
インターフェロン磨法等も㢦みられ，最近では，進展例 


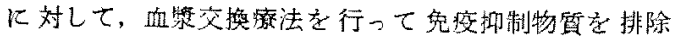
し，兔疫能を间上させる試みがなされている

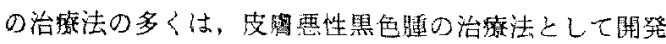

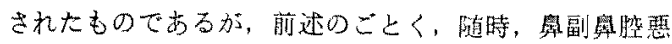

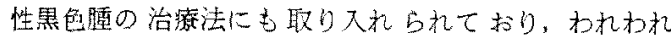
む、これらの治療法を併用した，いわゆる集学的治療を

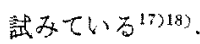

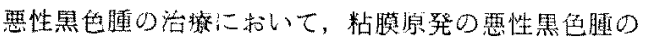

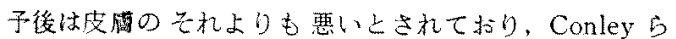

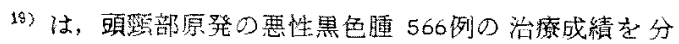

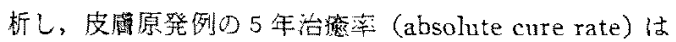
$27.8 \%$ でったのた対し，粘膜原発例の之れは8\%であ

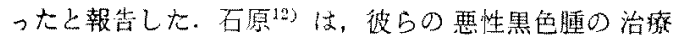
成辕老, stage Ia $\bigcirc 5$ 年生存率は $94.2 \%$, stage Ib, stage II，の5年生存率は古机れ $38.9 \% ， 14.8 \%$, stage

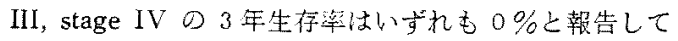

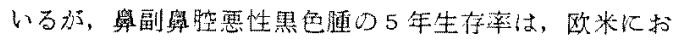

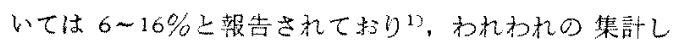
た治療成縝声同槏であった。

\section{Vまとめ}

1965年名51981年立て017年閒の本邦文献加5涉悦し

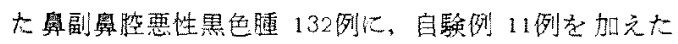
143例の統計的钼祭を行い，次のような結果を得た。

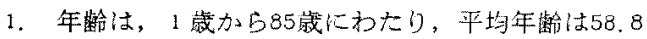
藏であった。

2. 性別は，男：女＝1.24:1 と男性にかずかに多か った.

3. 年平均の発生頻度は 8.4例を, 近年, 增加傾向觉 裙めた。

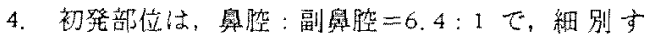

ると，齄中隔，鼻甲介，鼻道の順に多加た。

5. 左右别頻度は，左：右二1.7:1 であった。

6.リンバ節轱移，または，遠陆転移は，96例中60例 飞諰め，渦半数は全射枟移であった。

7. 予後は，度家等のそれよりもさらに不良で，治療 成績の向上には，早期発見に加えて，広泀切除，凍結手 術, 化学療法, 免疫療法, 放射線療法等茫合併した集学 的治旗が必要上教えられた。

\section{参考文献}

1) Batsakis J G: Tumors of the head and neck. Willams \& Wilkins Co, Baltimore, 1976.

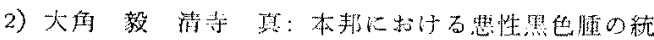

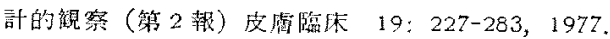

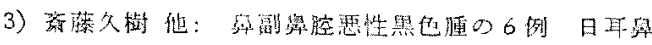
$80: 14-27,1977$,

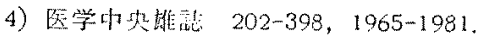

5) Ariel I M: Malignant melanoma. AppletonCentury-Crofts, New York, 1981.

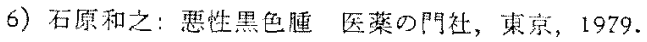

7) Moore E S and Martin H: Melanoma of the upper respiratory tract and oral cavity. Cancer 8: $1167-1176,1955$.

8) Allen A C and Spitz S: Malignant Melanoma; A clinicopathological analysis of the criteria for diagnosis and prognosis. Cancer 6: $1-45,1953$.

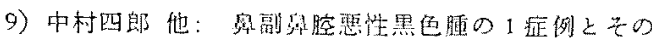

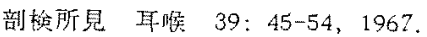

10) Holderaft $J$ and Gallagher $J C$ : Malignant melanomas of the nasal and paranasal sinus mucosa. Ann Otol 78: 5-20, 1969.

11) 石原和之: 覀性黑色嗹 内档 49：1379-1383，1982.

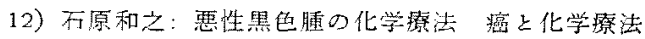
7: $747-755,1980$.

13) Bellet $R$ E et al: Chemotherapy of malignant melanoma. Cancer Chemotherapy 3: 225-242, 1978.

14) Morton D L et al: Immunological factors which influence response to immunotherapy in malignant melanoma. Surgery 68: $158-164,1970$.

15) Harrison DF $\mathrm{N}$ : Malignant melanomata arising in the nasal mucous membrane. J Laryng Otol 90: 993-1005, 1976.

16) Israel $L$ et al: Plasmapheresis in patients with disseminated cancer: Clinical results and correlation with changes in serum protein. Cancer 40: $3146-3154,1977$.

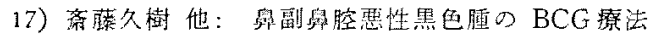
日耳开 83: 647-653, 1980.

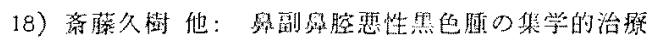
癡上化学瘵法 9：1555-1561，1982.

19) Conley J and Hamaker R C: Melanoma of the head and neck. Laryngoscope 87: 760-764, 1977.

(腺稿受付 昭和 57.9 .6 日)

別刷請求先 $\bar{T} 036$ 弘前市在府町 5

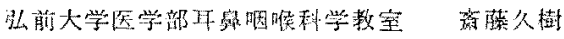

